\title{
Fracture Toughness of Rigid Polymeric Foams. A review
}

\author{
liviu marsavina ${ }^{1}$ and Emanoil Linul ${ }^{2}$ \\ ${ }^{1}$ Universitatea Politehnica din Timisoara \\ ${ }^{2}$ POLITEHNICA University of Timisoara
}

April 28, 2020

\begin{abstract}
Polymeric foams have good capacity of absorbing energy in compression, but are brittle in tension. Linear Elastic fracture Mechanics is successfully applied to assess the integrity of structures with polymeric foams. The fracture toughness represents an important parameter. The different approaches to estimate the fracture toughness of polymeric foams are reviewed, analytical and numerical micromechanical models and experimental investigations. Focus is given on the parameters influencing the fracture toughness of polymeric foams like specimen type, solid material, density, loading speed, size effect and temperature. Data on mixed mode loading and dynamic fracture toughness are also presented. The last part of the paper presents some results to increase the fractured toughness by reinforcing of polymeric foams.
\end{abstract}

\section{Hosted file}

Fracture of Polymeric Foams-v5.docx available at https://authorea.com/users/315092/articles/ 445450-fracture-toughness-of-rigid-polymeric-foams-a-review 